\title{
Interim Action Record of Decision Remedial Alternative Selection \\ - TNX Area Groundwater Operable Unit
}

by

E. R. Palmer

Westinghouse Savannah River Company

Savannah River Site

Aiken, South Carolina 29808

This paper was prepared in connection with work done under the above contract number with the U.S.

Department of Energy. By acceptance of this paper, the publisher and/or recipient acknowledges the U.S. Government's right to retain a nonexclusive, royalty-free license in and to any copyright covering this paper, along with the right to reproduce and to authorize others to reproduce all or part of the copyrighted paper.

DSTRIBUTION OF MIS DOCUMENT IS UNLIMITED 


\section{DISCLAIMER}

Portions of this document may be illegible electronic image products. Images are produced from the best available original document. 


\section{DISCLAIMER}

This report was prepared as an account of work sponsored by an agency of the United States Government. Neither the United States Government nor any agency thereof, nor any of their employees, makes any warranty, express or implied, or assumes any legal liability or responsibility for the accuracy, completeness, or usefulness of any information, apparatus, product, or process disclosed, or represents that its use would not infringe privately owned rights. Reference herein to any specific commercial product, process, or service by trade name, trademark, manufacturer, or otherwise does not necessarily constitute or imply its endorsement, recommendation, or favoring by the United States Government or any agency thereof. The views and opinions of authors expressed herein do not necessarily state or reflect those of the United States Government or any agency thereof.

This report has been reproduced directly from the best available copy.

Available to DOE and DOE contractors from the Office of Scientific and Technical Information, P. O. Box 62, Oak Ridge, TN 37831; prices available from (423) 576-8401.

Available to the public from the National Technical Information Service, U. S. Department of Commerce, 5285 Port Royal Road, Springfield, VA 22161. 
WSRC-TR-94-0375

Rev 1

October 1994

\section{Interim Action Record of Decision Remedial Alternative Selection-TNX Area Groundwater Operable Unit ${ }^{(U)}$}

Westinghouse Savannah River Company Savannah River Site Aiken, SC 29808

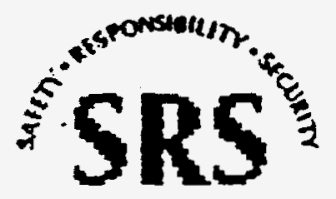

Prepared for the U.S. Department of Energy under contract no. DE-ACO9-89SR18035 


\section{Contents}

Declaration for the Record of Decision 1

Unit Name and Location 1

Statement of Basis and Purpose 1

Assessment of the Unit 1

Description of the Selected Remedy 1

Recirculation Wells 2

Extraction Wells with an Air Stripper 2

Declaration Statement $\cdot 3$

Section I Site and Operable Unit Names, Locations, and Descriptions

Section II Operable Unit History and Compliance History 7

Operable Unit History 7

Compliance History 7

Section III Highlights of Community Participation 8

Section IV Scope and Role of Operable Unit within the Site Strategy 10

Section V Summary of Operable Unit Characteristics 11

Section VI Summary of Operable Unit Risks 20

Comtaminated Media 20

Contaminants of Concern 20

Interim Risks 20

\section{Section VII Description of Alternatives 21}

Alternative 1-No Interim Action, Invoke Institutional Controls

Treatment Components 21

Engineering Controls 21

Institutional Controls 21

Implementation Requirements 21

Estimated Construction and Operation and Maintenance Costs

ARARs Associated with the Considered Aternative 22

Alternative 2-Hybrid Groundwater Corrective Action 22

Engineering Controls 22

Institutional Controls 24

Impiementation Requirements 24

Estimated Construction and Operation and Maintenance Costs 
ARARs Associnted with the Considered Alternntive 24

Section VIII Summary of Comparative Analysis of Alternatives $\mathbf{3 0}$

Description of Nine Evaluation Criteria 30

Section IX Selected Remedy 32

Section X Statutory Determination 33

Section XI Explanation of Significant Changes 34

References 35

Appendix A Responsiveness Summary 36 


\section{List of Figures}

1 Location of the TNX Area Groundwater Operable Unit CERCLA unit at SRS

2 Topographic Map of the TNX Area and Local Surroundings

3 Geophysical and Lithologic Log Showing Units and Hydrogeologic Section of the TNX Area

4 TNX Water Table Map (Average Elevation for 1991)

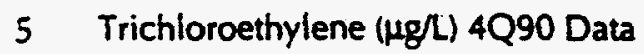

6 Nitrate as $N(\mu \mathrm{g} / \mathrm{L}) 4 \mathrm{Q} 90$ Data

7 4Q90 Field pH Mercury Posting Map for Water Table Wells at TNX

84 Q90 Gross Alpha and Total Radium Posting for Water Table Wells at TNX

9 Sources of Risk to Onsite Worker

10 Risks for Different Exposure Scenarios

11 Flow Patterns for a Recirculation Well System

12 Capture Zone of a Hypothetical Hybrid Groundwater Corrective Action for TNX

\section{List of Tables}

1 List of Constituents Detected Above the Primary Drinking Water Standard in Groundwater at TNX Area from 3Q88 to 1Q92

2 Applicable or Relevant and Appropriate Requirements for the Hybrid Groundwater Corrective Action

3 Evaluation of Interim Response Actions 


\title{
Declaration for the Record of Decision
}

\author{
Unit Name and Location
}

TNX Area Groundwater Operable Unit CERCLA Unit

Savannah River Site

Aiken County, South Carolina

Appendix $C$ of the Federal Facility Agreement (FFA) lists this Comprehensive Environmental Response, Compensation, and Liability Act (CERCLA) unit as Groundwater, TNX.

\section{Statement of Basis and Purpose}

This document presents the selected interim remedial action for the TNX Area Groundwater Operable Unit at the Savannah River Site (SRS), which was developed in accordance with CERCLA of 1980, as amended by the Superfund Amendments and Reauthorization Act (SARA) of 1986, and to the extent practicable, the National Oil and Hazardous Substances Pollution Contingency Plan (NCP). This decision is based on the Administrative Record File for this specific CERCLA unit.

The State of South Carolina concurs with the selected interim action remedy.

\section{Assessment of the Unit}

The TNX Area is a pilot scale test facility for the Savannah River Technology Center . (SRTC). The pilot scale facilities are used to provide technical support to various SRS production areas. From 1953 to August 1988, wastewater generated by research performed in the TNX Area was disposed of in seepage basins. In August 1988, wastewater was rerouted to the TNX Effluent Treatment Facility.

In 1980, the first series of groundwater monitoring wells were installed in the TNX Area. The first series of monitoring wells were determined to be inadequate and were abandoned and replaced in 1984. The groundwater sampling data from the new wells indicated that seepage from the unlined basins, leakage from the process sewers, and leachate from other activities in the area resulted in soil and groundwater contamination throughout the TNX Area. Analysis of surface water samples collected from the swamp adjacent to the Savannah River indicate that groundwater contaminated with Chlorinated Volatile Organic Compounds (CVOCs) is outcropping in the swamp before it reaches the river. No contaminants from the plume were detected in the Savannah River. Actual or threatened releases from this site, if not addressed by implementing the response action selected in this Record of Decision (ROD), could present an endangerment to public health. welfare, or the environment.

\section{Description of the Selected Remedy}

The TNX Area groundwater and the source areas contributing to contamination of the ground water are in various stages of the CERCLA investigation and remedy selection process. This ground water interim action will serve to mitigate the further migration of the groundwater plume hotspot while also removing contaminants from the groundwater. Fol- 
lowing investigation and remedy selection for the source units in the TNX Area. the groundwater unit will be reassessed and appropriate final remedial alternatives will be developed.

The selected altemative to achieve the interim action goals is Alternative 2. Hybrid Groundwater Corrective Action (HGCA). The HGCA includes one recirculation well and a series of groundwater extraction wells with an air stripper. The conceptual design for the extraction system has three to five groundwater extraction wells with a combined flow rate of up to 60 gallons per minute. The target treatment level for tricholorethylene (TCE) in the extracted groundwater will be 5 ug/L prior to discharge to a NPDES outfall. The actual design of the remedial system will be addressed through the remedial design process.

\section{Recirculation Wells}

Recirculation wells are an emerging technology for in situ cleanup of CVOC contaninated groundwater. In recirculation wells, air is injected into a groundwater well. As the air rises to the surface in the well, it removes CVOCs from the water in the well by air stripping. Additionally, the air causes groundwater to flow upward in the well establishing a circulation system where water is drawn into the bottom of the well and discharged at the water table. The air is collected by a vacuum at the surface for treatment. The vacuum also recovers soil vapor from the unsaturated zone resulting in additional cleanup.

\section{Extraction Wells with an Air Stripper}

The migration of the contaminated groundwater plume hotspot will be intercepted by a series of water wells known as extraction wells. The extraction wells are used to drawdown the water table and collect contaminated groundwater. Drawdown from the extraction wells produces a capture zone that prevents the further migration of contamination from the site. The contaminated groundwater that is collected by the extraction wells will be treated by an air stripper. Treated groundwater will be discharged to a permitted outfall. The air stripper can also be used to treat contaminated water from other cleanup activities, such as groundwater sampling. Air emission from the air stripper and recirculation well will be treated as necessary to comply with South Carolina Department of Health and Environmental Control (SCDHEC) air pollution regulations.

In addition to TCE, the main contaminant of concern, CVOCs, mercury, gross alpha, and nitrate will be monitored in the effluent from the treatment system to ensure that they do not exceed discharge limits. If they begin to exceed discharge limits, the well causing the exceedance will be identified through sampling, and discharges from that well will be treated using methods similar to ion exchange or reverse osmosis. 


\section{Declaration Statement}

This interim action is protective of human health and the environment. complies with for waives) Federal and South Carolina applicable or relevant and appropriate requirements (ARARs) for this limited scope action, and is cost-effective. ARARs pertaining to aquifer restoration to Safe Drinking Water Act (SDWA) Maximum Contaminant Levels (MCLs) do not apply to this action because this limited scope interim action is pan of an overall remedy that will attain (or waive) all ARARs for the final action. Although this interim action is not intended to fully address the statutory mandace for permanence and treatment to the maximum extent practicable, this interim action utilizes treatment and. accordingly, is in furtherance of that statutory mandate. Since this action does not constitute the final remedy for the TNX Area Groundwater Operable Unit, the statutory preference for remedies that employ treatment that reduces toxicity, mobility, or volume as a principal element. although partially addressed in this remedy, will be addressed by the final response action. Subsequent actions are planned to fully address the threats posed by the conditions at this unit. Because this remedy will result in hazardous substances remaining onsite above health-based levels. a review will be conducted to ensure that the remedy continues to provide adequate protection of human health and the environment within five years after commencement of the remedial action. Since this is an Interim Action Record of Decision, review of this unit and this remedy will be ongoing as the Department of Energy (DOE).continues to develop final remedial alternatives for the TNX Area Groundwater Operable Unit.

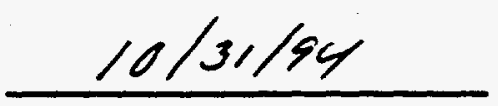

Date

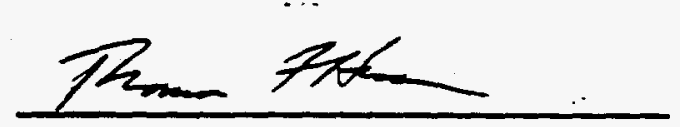

Thomas F. Heenan

Assistant Manager for Environmental Restoration and Waste Management U.S. Deparment of Energy

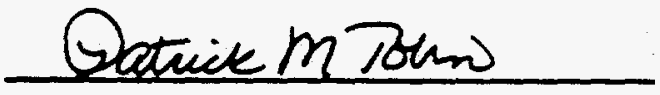

Date

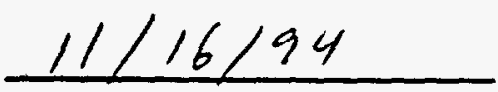

Date

John H. Hankinson. Jr. Regional Administrator U.S. Environmental Protection Agency Region IV

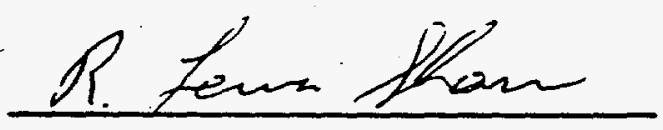

R. Lewis Shaw Deputy Commissioner Environmental Quality Control South Carolina Department of Health and Environmental Control 


\section{Site and Operable Unit Names, Locations, and Descriptions}

The Savannah River Site (SRS) occupies approximately 300 square miles adjacent to the Savannah River, principally in Aiken and Barnwell counties of South Carolina (Figure 1). SRS is a secured facility with no permanent residents. The Site is approximately 25 miles southeast of Augusta, Georgia and 20 miles south of Aiken. South Carolina. According to 1990 census data, the average population densities (in people/square mile) for the surrounding South Carolina counties are 111 for Aiken County, 36 for Barnwell County. and 28 for Allendale County and for the surrounding Georgia counties. 228 for Columbia County. 524 for Richmond County, 25 for Burke County, and 21 for Screven County. The population within a 50-mile radius of SRS is 634,784 people.

SRS is owned by the U.S. Department of Energy (DOE). Westinghouse Savannah River Company (WSRC) provides management and operating services for DOE. SRS has historically produced tritium, plutonium, and other special nuclear materiais for national defense. The Site has also provided nuclear materials for the space program and medical, industrial. and research efforts. Chemical and radioactive waste are by-products of nuclear material production processes. Hazardous substances, as defined by the Comprehensive Environmental Response, Compensation. and Liability Act (CERCLA), are present in the environment at SRS. Appendix C. RCRACERCLA Units List, of the Federal Facility Agreement. (FFA, 1993) lists the TNX Area Ground water Operable Unit.

The TNX Area is located adjacent to the Savannah River in the southwestern portion of SR'S (see Figure 1). Pilot-scale testing and evaluation of chemical processes in the TNX Area included support of the Defense Waste Processing Facility, separations areas, and fuel and target manufacturing areas. Wastewater generated during support of the previously identified initiatives was discharged to unlined earthen basins through a network of process sewers.

- The TNX Area is one quarter of a mile east of the Savannah River. between Upper Three Runs Creek to the north and Fourmile Creek to the south, at an elevation of $150 \mathrm{feet}$ above mean sea level (MSL). Local topography is relatively flat with a slope toward the east, away from the Savannah River.

Immediately west of the TNX Area is a swamp adjacent to the Savannah River at 95 feet above MSL (see Figure 2). A small terrace divides the swamp and serves as the bank of the river during high stages. The terrace in the swamp is covered by bottomland hardwoods. and the swamp west of the terrace has stands of cypress and tupelo typical of Savannah River swamps. Typical fauna for bottomland handwood forests includes, but is not limited to, salamanders, frogs, snakes, bats, squirrels, raccoons, skunks, weasels, and foxes. Large mammals include white-tailed deer and feral pigs. No endangered or threatened species have been identified in the vicinity of the TNX facility from previous surveys, nor do habitats exist there for the American alligator, red-cockaded woodpecker, the wood stork. or the shon-nosed sturgeon. 


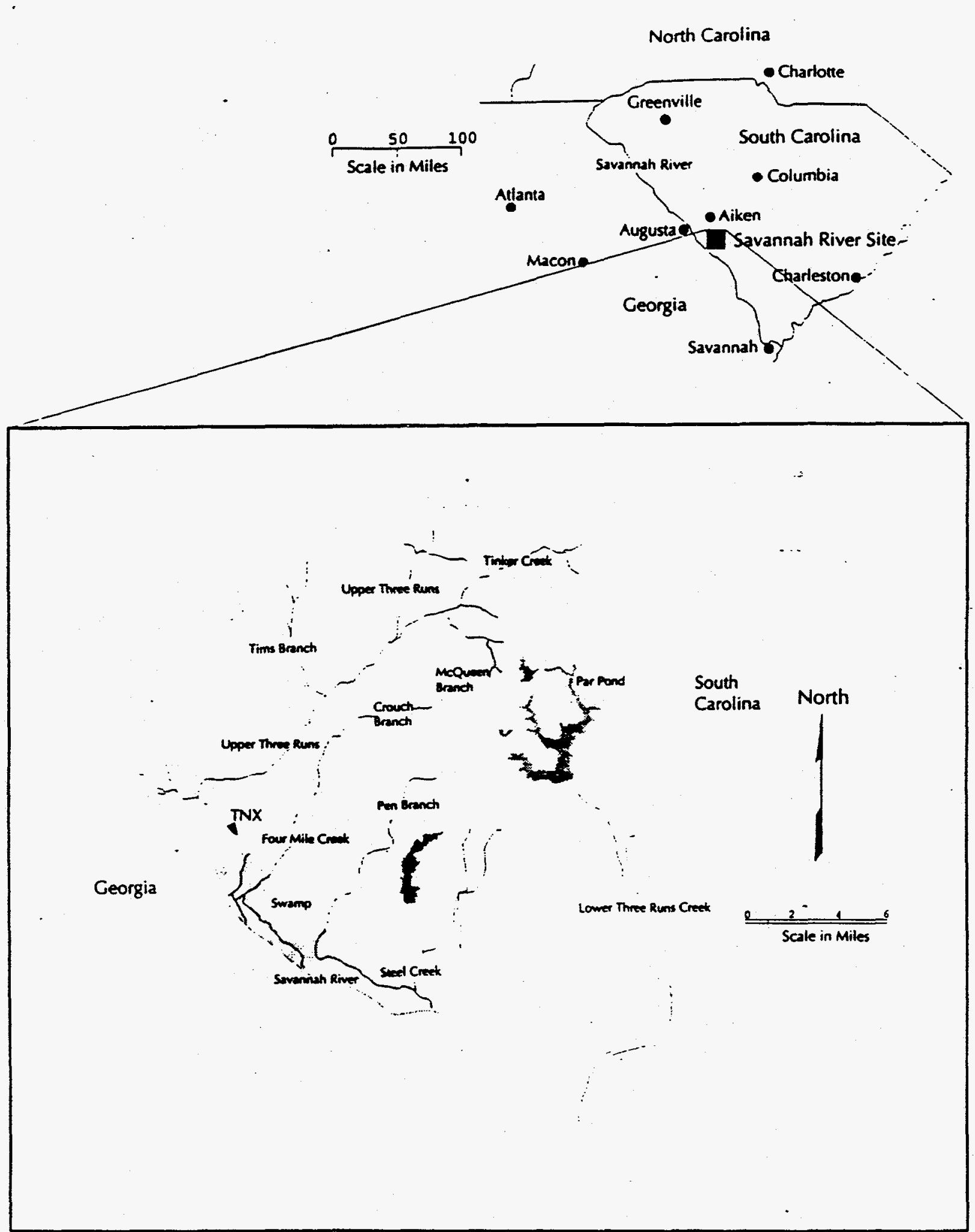

Figure 1. Location of the TNX Area Groundwater Operable Unit CERCLA unit at SRS. 


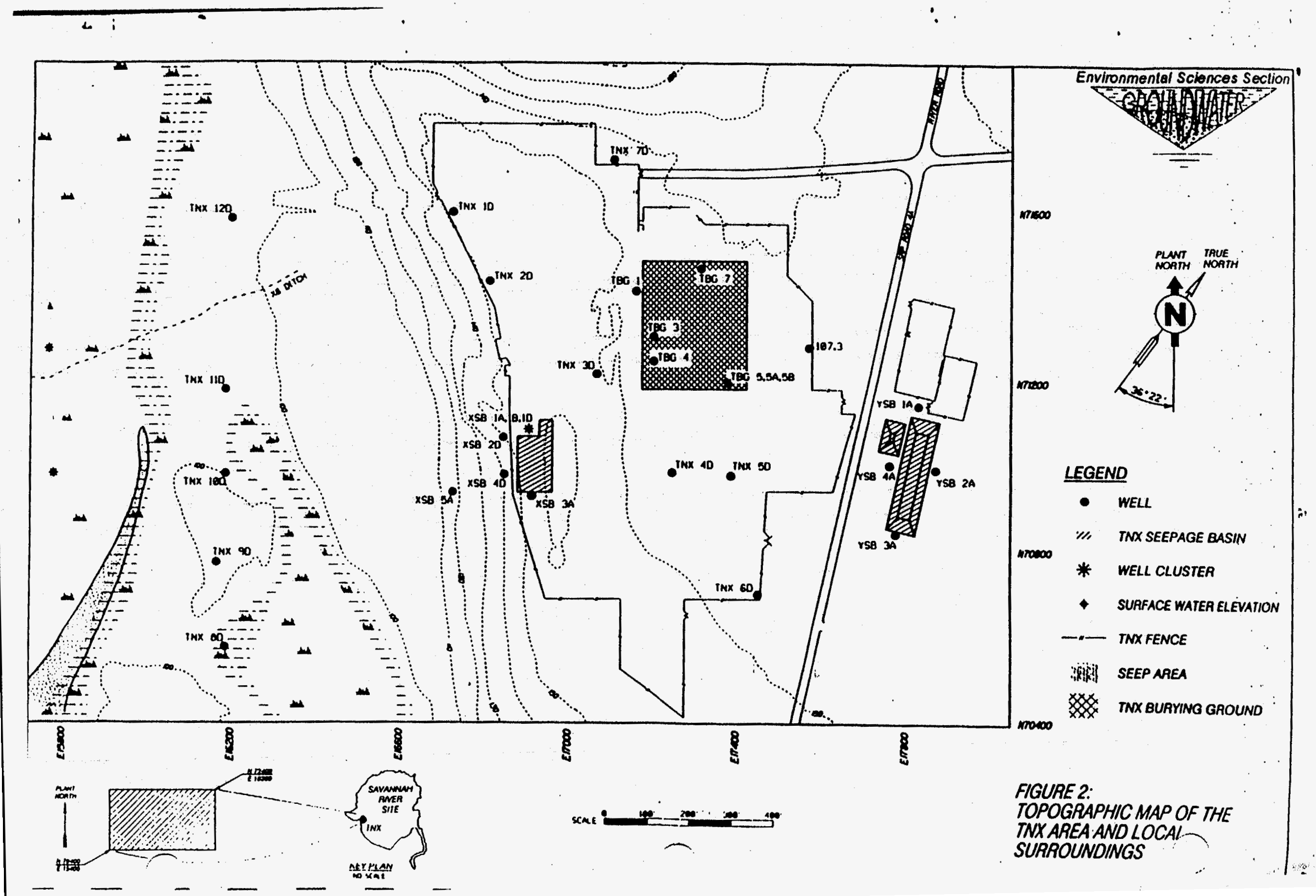




\section{Operable Unit History and Compliance History}

\section{Operable Unit History}

The TNX Area is a pilot scale test facility for the SRTC. The pilot scale facilities are used to provide technical support to various SRS production areas. From 1953 to August 1988. wastewater generated by research performed in the TNX Area was disposed of in seepage basins. In August 1988, wastewater was rerouted to the TNX Effluent Treatment Facility.

In 1980, the first series of groundwater monitoring wells was installed in the TNX Area. The first series of monitoring wells was determined to be inadequate and were abandoned and replaced in 1984. The groundwater sampling data from the new wells indicated that seepage from the unlined basins, leakage from the process sewers. and leachate from other activities in the area resulted in soil and groundwater contamination throughout the TNX Area. Analysis of surface water samples collected from the swamp adjacent to the Savannah River indicates that groundwater contaminated with CVOCs is outcropping in the swamp before it reaches the river. No contaminants from the plume were detected in the Savannah River. An environmental impact statement addressing groundwater contamination caused by site operations was submitted for public comment in 1987 (DOE, 1987).

\section{Compliance History}

On December 21, 1989. SRS was placed on the National Priorities List (NPL). A site placed on the NPL comes under the jurisdiction of CERCLA. In accordance with Section 120 of CERCLA. DOE negotiated a Federal Facility Agreement (FFA, 1993) with the U.S. Environmental Protection Agency (EPA) and SCDHEC to coordinate cleanup activities at SRS into one comprehensive strategy that fulfills Resource Conservation Recovery Act (RCRA) Section 3004(u) and CERCLA assessment, investigation, and response action requirements. The FFA lists the TNX Area Groundwater Operable Unit as a CERLCA unit requiring further evaluation using the CERCLA Remedial Investigation (RI) process to determine the actual or potential impact to human health and/or the environment.

Public participation requirements are listed in Sections 113 and 117 of CERCLA. These requirements include the establishment of an Administrative Recond File which documents the selection of cleanup alternatives and provides for review and comment by the public. The SRS Public Involvement Plan (PIP)(WSRC. 1991) is designed to facilitate public involvement in the decision making processes for permitting, closure, and selection of remedial alternatives. The PIP addresses the requirements of RCRA. CERCLA. and the National Environmental Policy Act (NEPA). Section 117(a) of CERCLA. 1980, as amended by the Superfund Amendments and Reauthorization Act (SARA) of 1986. requires the preparation of a proposed plan as part of the site remedial process. The Inserim Action Proposed Plan for the TNX Area Groundwater Operable Unit, which is part of the Administrative Record File, highlights key aspects of the assessment and investigation phases of the remediation process and identifies the preferred interim action alternative for remediation of the TNX Area Groundwater Operable Unit. 


\section{Highlights of Community Participation}

The Administrative Record File, which contains the information upon which the selection of the response action was made, is available at the following locations:

U.S. Department of Energy Public Reading Room

Gregg-Graniteville Library

University of South Carolina-Aiken

171 University Parkway

Aiken, South Carolina 29801

(803) 641-3465

Thomas Cooper Library

Government Documents Department

University of South Carolina

Columbia, South Carolina 29802

(803) $777-4866$

Similar information is available through the following repositories:

Reese Library

Augusta College

2500 Walton Way

Augusta, Georgia 30910

(404) 737-1744

Asa H. Gordon Library

Savannah State College

Tompikins Road

Savannah. Georgia 31404

(912) $356-2183$

The public was notified about the comment period for the TNX Area Ground water Operable Unit through mailings of the SRS Environmental Bulletin, a newsletter sent to more than 1400 citizens in South Carolina and Georgia, and through notices in the Aiken Standard, the Allendale Citizen Leader, the Bamwell Counny Banner, the Barnwell People-Sentinel, the North Augusta Post, The State, and The Augusta Chronicle newspapers.

The 30-day public comment period began on August 15. 1994, for the Interim Action Proposed Plan for the TNX Area Groundwater Operable Unit. Responses to comments are discussed in the Responsive Summary (see Appendix A). The proposed plan included a means for requesting a public meeting to discuss the TNX Area and the proposed interim action. A public hearing was requested during the initial public comment period. As a result of the request for a public hearing. the public comment period was extended to October 13, 1994. and a public hearing was held on October 11. 1994. 
Two written comments were received on the LAPP. One of the comments only requested a public hearing, and the other comment pertained to permitting issues for the treatment system. 


\section{Scope and Role of Operable Unit within the Site Strategy}

Past operations within the TNX Area led to the contamination of the area's groundwater. Several source units have been identified in the TNX Area which contributed to the groundwater contamination. These units include the Old TNX Seepage Basin. the New TNX Seepage Basin, and the TNX Burying Ground. Operations associated with these units. as well as leakage from process sewers and leachate from other site activities. contributed to the groundwater contamination.

The areas contributing to the groundwater contamination will be investigated pursuant to the requirements of the NCP and the FFA. Following investigation of these areas. appropriate cleanup alternatives will be developed.

The groundwater system in the TNX Area has been adequately characterized to identify the need for a limited scale action and support the design and implementation of a system to begin controlling and remediating groundwater contamination. Final cleanup alternatives for the groundwater will be developed following remedy selection for the source units.

A limited scale interim action is desired to control the further migration of the groundwater contamination hotspot, prevent the further degradation of the groundwater system. and . begin contaminant mass removal from the groundwater contamination hotspot. An interim action addressing the most contaminated groundwater at the TNX Area through plume stabilization and contaminant removal will be protective of human health and the environment. will not be inconsistent with potential future cleanup activities. and reduce the scope of future final actions. 


\section{Summary of Operable Unit Characteristics}

- TNX is underlain by two aquifer systems-a deep aquifer system and a shallow aquifer system. The systems are separated by $a$ thick layer of clay and silt with thin sand lenses approximately 50-feet thick (see Figure 3). The clay and silt layer greatly reduces flow between the aquifer systems. An upward gradient between the deep aquifer system and the shallow aquifer system equals about 55 feet of water (24 psi). The upward gradient results in upward groundwater flow from the deep-aquifer system to the shallow aquifer system. Domestic and process water for the TNX Area is produced from the deep aquifer system. Lateral groundwater flow in the deep and shallow aquifers beneath TNX is to the west-northwest direction towards the Savannah River.

The shallow aquifer system is composed of a water table aquifer and a semi-confined aquifer. Depth to the water table varies from zero to 50 feet in the area of groundwater contamination. Groundwater flow in the shallow aquifer system is toward the Savannah River. The water table aquifer crops out in the swamp between the Savannah River and the TNX Area (see Figure 4). Groundwater contamination at $\operatorname{TNX}$ was detected only in the water table aquifer in the shallow aquifer system.

Groundwater monitoring wells in the TNX Area are sampled and anialyzed for a wide range of parameters. The parameters analyzed include indicators of water quality (pH. alkalinity. specific conductivity. gross alpha, nonvolatile beta. etc.) and specific chemical constituents. The chemical constituents include organic compounds, specific radionuclides, and nonradiological inorganic species. Stallow groundwater at TNX has low ionic strength, is . slightly to moderately acidic, aerobic, and has a small amount of total dissolved solids. This general groundwater chemisty is consistent with the local aquifer materials, specifically. highly leached sand with some silt and lesser amounts of clay. The groundwater contamination can be divided into two categories, organic and inotganic contamination.

The water table aquifer at TNX is contaminated with CVOCs, primarily trichloroethylene (TCE), tetrachloroethylene (PCE), and carbon terrachloride (see Table 1). The CVOC contamination underlays eight acres, has a maximum thickness of 20 feet. and contains approximately six gallons of TCE. Trans-1,2-diehloroethylene, a product of natural aerobic biodegradation of TCE and PCE, has been measured in some of the wells with TCE. The absence of vinyl chloride in the groundwater suggests that the biodegradation is following an aerobic pathway. A concentration map for TCE illustrates the lateral extent of CVOC migration (see Figure 5). 1,1.1-trichloroethane and chloroform were also detected in elevated concentrations, but did not exceed Primary Drinking Water Standards (PDWS).

At one time, benzene was detected above the PDWS. A replicate analysis by the same laboratory yielded a result of $3 \mu \mathrm{g} /$, and both resuits from a replicate analysis performed by an independent laboratory on a split sample were below detection of $1 \mu \mathrm{g} / \mathrm{L}$. The replicate and duplicate analyses provide strong evidence to suggest that the one reported value. which exceeds the PDWS, was not representative of the field conditions. 
Table 1.List of Constituents Detected Above the Primary Drinking Water Standard in Groundwater at TNX Area from $3 Q 88$ to $1 Q 92$

\begin{tabular}{|c|c|c|c|c|c|c|}
\hline \multirow{2}{*}{ Constituent } & \multirow{2}{*}{$\begin{array}{l}\text { Primary Drinking } \\
\text { Water Standard Value }\end{array}$} & \multicolumn{3}{|c|}{ Meximum } & \multicolumn{2}{|c|}{ Most Current } \\
\hline & & Result & Well & Date & Result (e) & Date \\
\hline Trichloroethylexe & 5 & 4800 & TBGS & $9 / 18 / 90$ & 1100 & $3 / 16 / 91$ \\
\hline Tetrachioroethylene & 5 & 110 & XSBID & $3 / 27 / 89$ & 5.25 & $2 / 5 / 92$ \\
\hline Carbon Tetrachloride & 5 & 750 & TBG4 & $7 / 3 / 89$ & 270 & $3 / 15 / 91$ \\
\hline Chloroform & $100^{\circ}$ & 221 & XSB1D & $3 / 27 / 89$ & LT 1 & $2 / 5 / 92$ \\
\hline Benzene & 5 & 97 & TBG7 & $12 / 5 / 89$ & LT I & $2 / 3 / 92$ \\
\hline Lindane & 0.2 & $0.28^{b}$ & $\mathrm{TN} \times 2 \mathrm{D}$ & $377 / 91$ & LT 0.005 & $2 / 5 / 92$ \\
\hline Endrin & 0.2 & $0.63^{b}$ & TNX2D & $37 n 91$ & LT 0.006 & $2 / 5 / 92$ \\
\hline Mercury & 2 & 4.39 & TBG4 & 9/9/89 & 3.7 & $3 / 15 / 91$ \\
\hline Gross Alpha (pCi/L) & 15 & 80 & TBG3 & $6 / 14 / 89$ & 5.70 & $9 / 4 / 91$ \\
\hline Nitrate as Nitrogen & 10000 & 98600 & TBG4 & $12 / 10 / 90$ & 43200 & $3 / 15 / 91$ \\
\hline Lead & 15 & $37.5^{\mathrm{C}}$ & XSBSA & $3 / 6190$ & 10.2 & $2 / 3 / 92$ \\
\hline Chromium & 100 & $197^{d}$ & XSB2D & $3 / 11 / 90$ & LT 4 & $2 / 4 / 92$ \\
\hline
\end{tabular}

All units are $\mu \mathrm{g} / \mathrm{L}$ unless noted otherwise.

a The level for trihalomethanes is set as $100 \mu \mathrm{g}$. Because brominated methane is rarely detected in SRS groundwater. it is presumed that most of the trihalomethanes present are chloroform.

b An insufficient number of detected results is available to determine if this is a representative value.

c Values have not been above PDWS since $1 Q 91$.

d This value is not believed to be representative of the maximum concentration because of laboratory error. Historical groundwater monitoring data confirms that chromium is not present at levets that exceed PDWS.

$\mathrm{LT}=$ less than

e Most current result for well in "Maximum" Summary.

Five inorganic constituents have been detected above PDWS: nitrate, mercury, gross alpha,

- lead, and chromium. Results from groundwater monitoring analyses show that nitrate is present in concentrations that exceed PDWS in several wells at TNX. Large quantities of industrial-grade nitric acid were used in the operations at TNX. Nitric acid dissociates into hydrogen and nitrate ions in water. Since nitrate is stable in aerobic groundwater, relatively mobile in groundwater, and was used throughout the TNX Area, it can be used as an indicator of the extent of groundwater contamination at TNX. Figure 6 is a concentration map for nitrate.

Mercury concentrations from monitoring well TBG4 consistently exceed PDWS. Very low $\mathrm{pH}(<4.2)$ and high nitrate concentrations have also been observed at well TBG4, indicating that the mercury was probably part of a spent nitric acid solvent solution disposed of at TNX. A solvent containing nitric acid and mercury was used at TNX in research on the chemical separations processes used at SRS.

Groundwater from monitoring well TBG4 also has elevated calcium, magnesium, and silica. which are the result of the dissolution of clay minerals in the sediments by very low $\mathrm{pH}$ water. The dissolution of clay minerals buffers the low $\mathrm{pH}$ water and is a natural chemical response to the addition of acid. The low $\mathrm{pH}$ conditions in the immediate vicinity of monitoring well TBG4 increase the solubility of mercury and reduce the number of sites available for mercury adsorption by occupying them with hydrogen ions. Since the groundwater is aerobic and contains chloride, the dissolved mercury is probably in the form of chloride 
complexes. As groundwater migrates downgradient away from the low $\mathrm{pH}$ mercury sourceterm. the concentration of mercury complexes is diluted and the groundwater pH increases. As the mercury complexes are diluted, they become unstable and break down, setting free the ionized mercury for adsorption to the soil. Soil downgradient of TBG4 has more sites available for mercury adsorption because of the increased $\mathrm{pH}$. The groundwater monitoring data suggest that these natural processes prevent mercury from migrating very far from the source-term (see Figure 7).

Gross alpha, an indicator of contamination by alpha-emitting radionuclides. is persistently elevated in two monitoring wells, TBG3 and TBG4, located immediately downgradient of the TNX Burying Ground (see Figure 8). Specific alpha emitters in the groundwater were identified by alpha spectroscopy; they were Ra-226. Th-228, 230, and 232, U-233. 234. 235. and 238, Pu-238, 239, 240, and 242, Am-24l and 243, and Cm-242, 243, 244, and 246. Isotopes of radium ( $\mathrm{Ra}$ ) and thorium (Th) are natural decay products of uranium (U), which is also naturally present in sediments. $U$ is a raw material used in several processes at SRS. but it occurs as a natural constituent in sediments as well. Plutonium (Pu), americum (Am), and curium $(\mathrm{Cm})$, commonly referred to as transuranics, do not occur naturally and are the result of artificial nuclear reactions such as the ones used at SRS. Ra-226 is the main contributor to gross alpha in groundwater throughout the TNX Area (see Figure 8).

Monitoring well XSBSA is the only well that has had lead concentrations that exceed PDWS. Lead concentrations have been steadily decreasing at this well and have not exceeded PDWS since the beginning of 1991. The lead probably comes from the galvanized steel screen in well XSB5, which is located less than ten feet upgradient of well XSB5A. The low $\mathrm{pH}(<5)$ of the groundwater in the vicinity of these wells leached lead from the galvanized screen when well XSB5 was active. The decreasing lead concentrations may indicate that the lead source was reduced by the abandonment of well XSBS.

Chromium (Cr) concentrations that exceeded PDWS at TNX were reported during one quarter of analysis and were not elevated prior to or following the quarter of suspect data. The suspect chromium analyses were conducted by the same laboratory and analyst.

Endrin and lindane (pesticides) have been occasionally ( $<50 \%$ of the time) above the PDWS at TNX.

Groundwater samples from the semiconfined aquifer at TNX have not exceeded the PDWS. The relative amounts of major ions in the semiconfined aquifer are different from the unconfined aquifer: iron. magnesium. calcium. sulfate. and $\mathrm{HCO}_{3}$ concentrations are higher in the semiconfined aquifer, and sodium. chloride. and $\mathrm{NO}_{3}$ are lower.

Tritium is below detection limits in the semiconfined aquifer as compared to the overiying unconfined aquifer, which has $2-4 \mathrm{pCi} / \mathrm{mL}$. (Average tritium levels in rainfall at TNX are 2-4 pCi/mL (Murphy, et. al.. 1993); the PDWS for tritium is $20 \mathrm{pCi} / \mathrm{mL}$.) The low tritium levels in the semiconfined aquifer at TNX indicate that ground water in the unconfined aquifer is not migrating into or impacting the semiconfined aquifer (Nichols, 1992). 

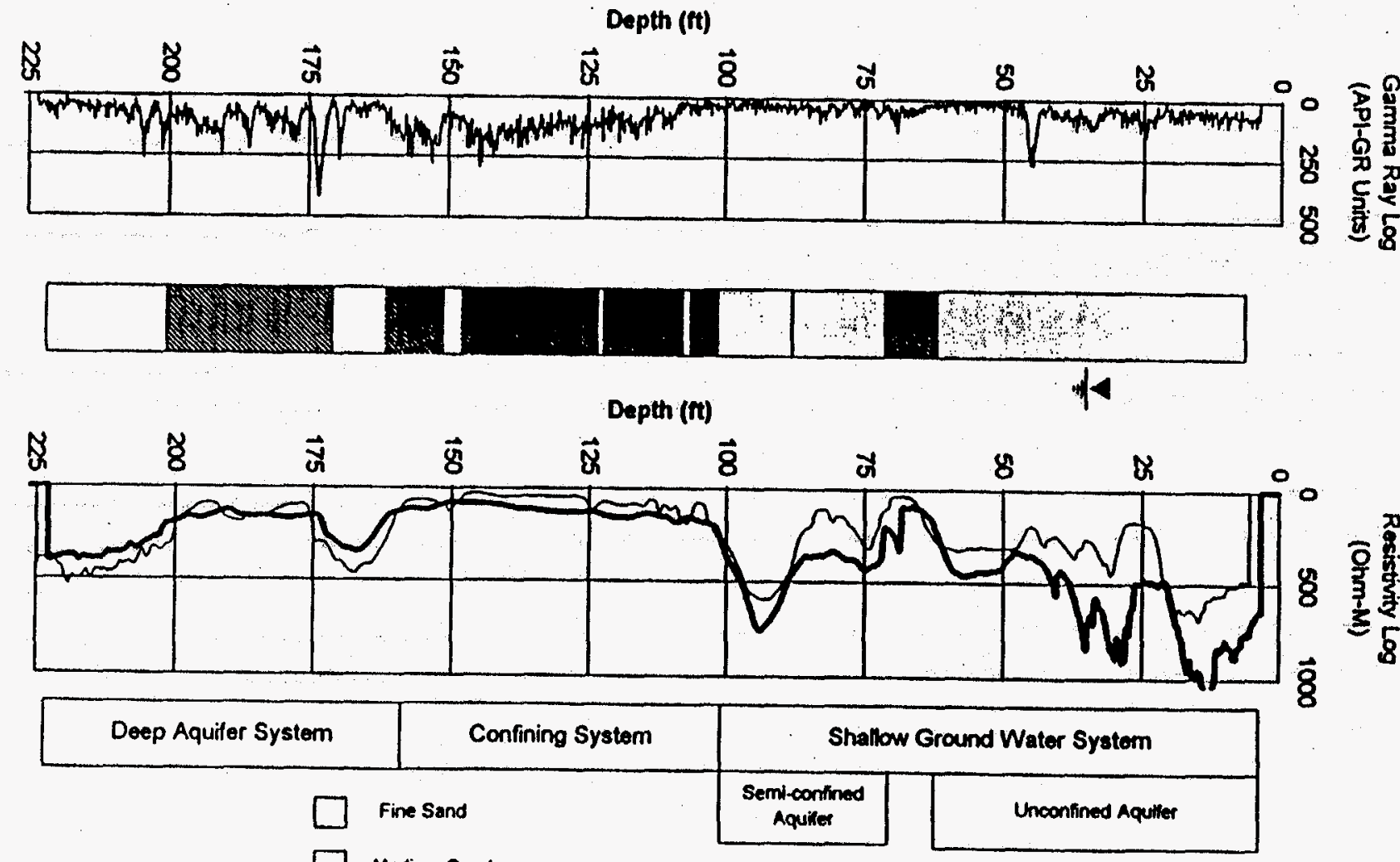

$\square$ Medium Sand

a cloyssin 


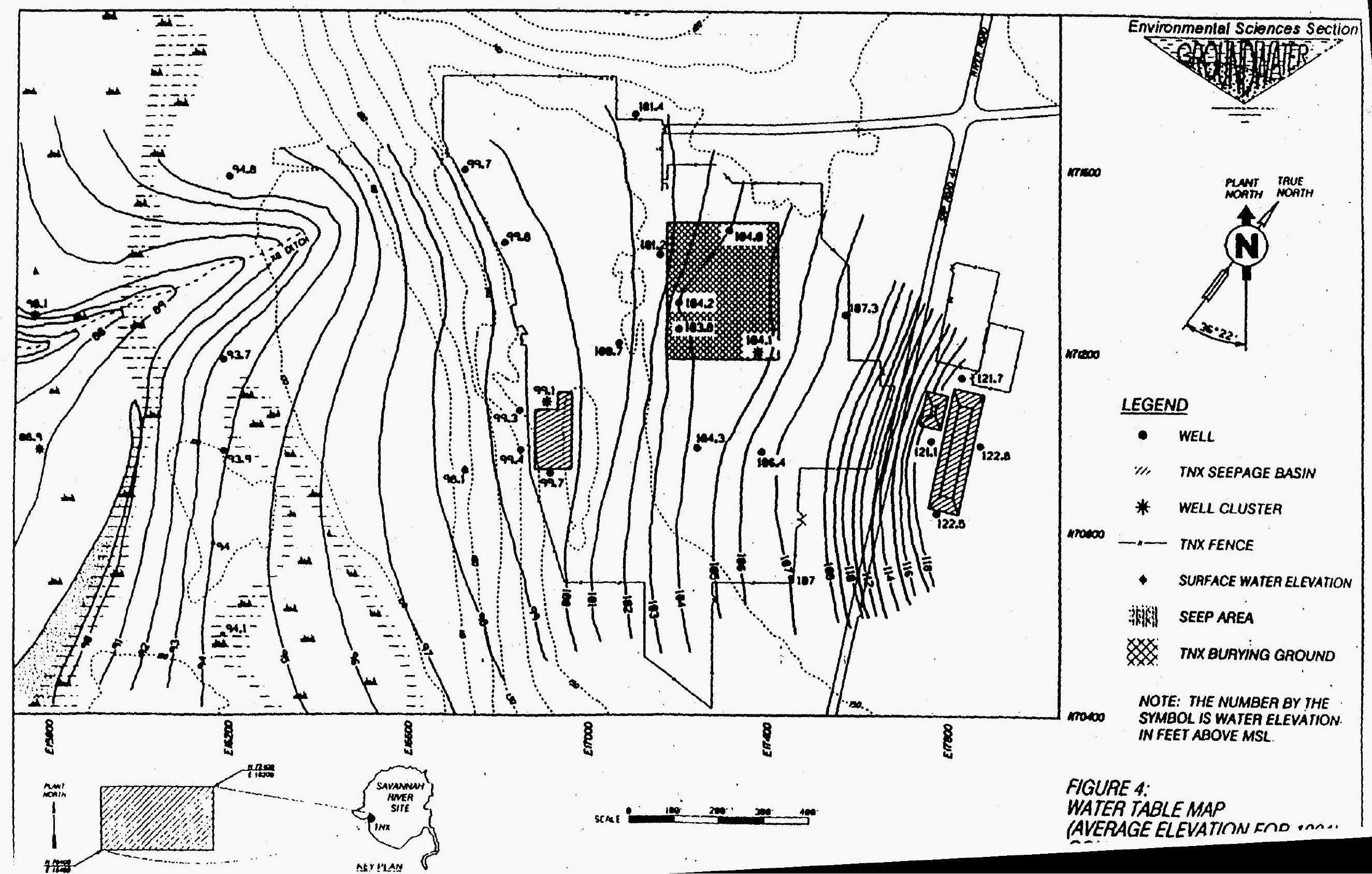




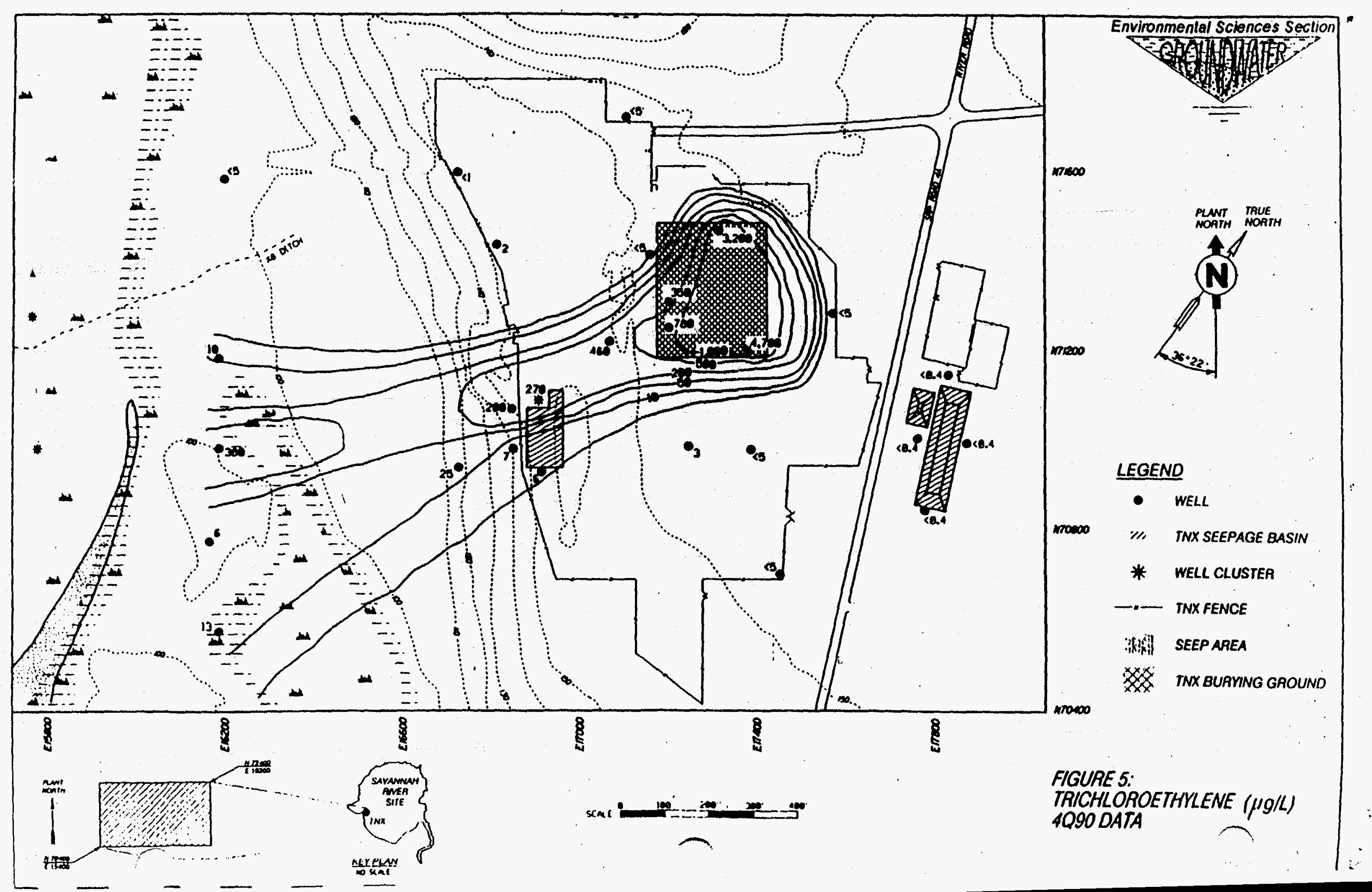




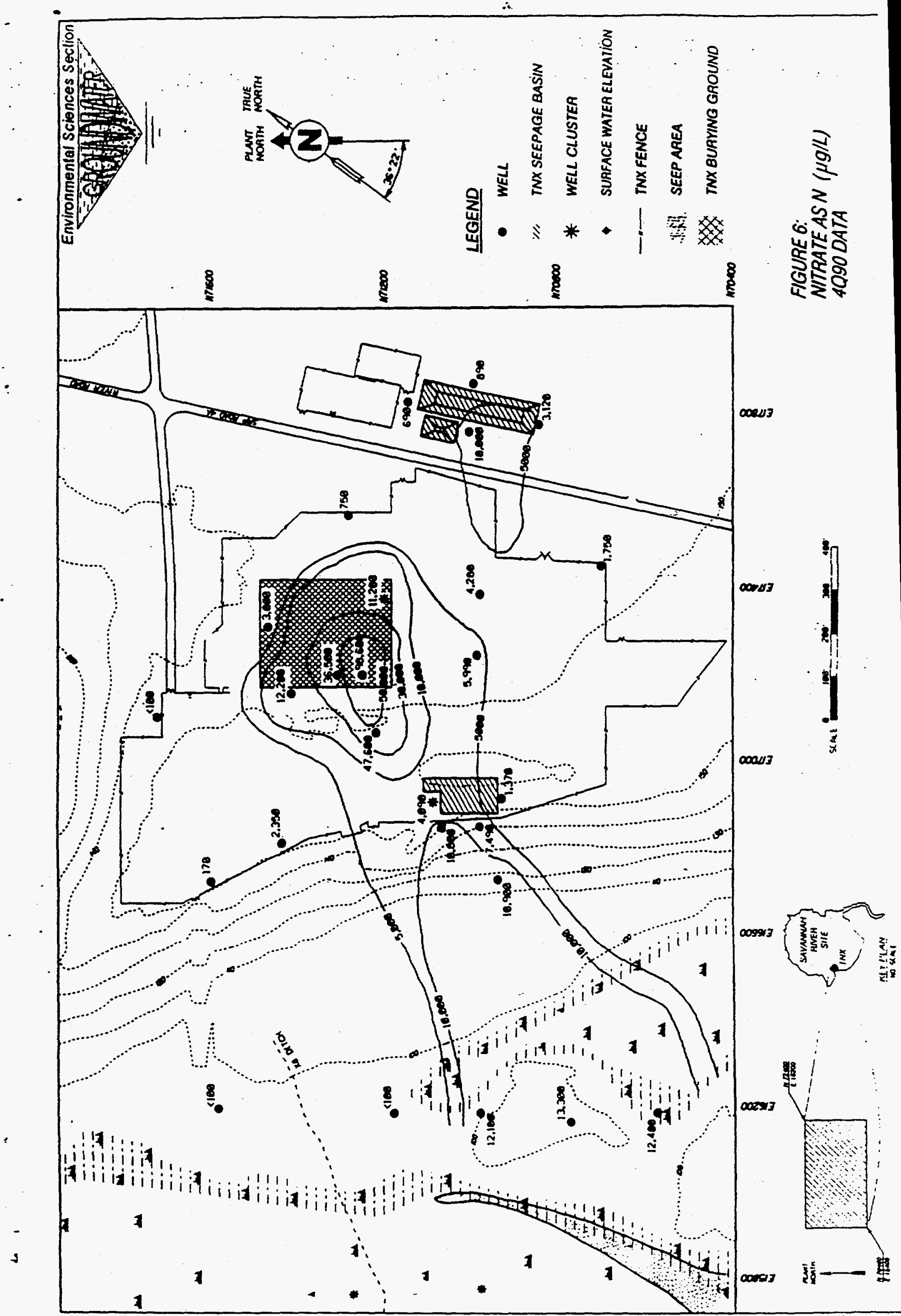




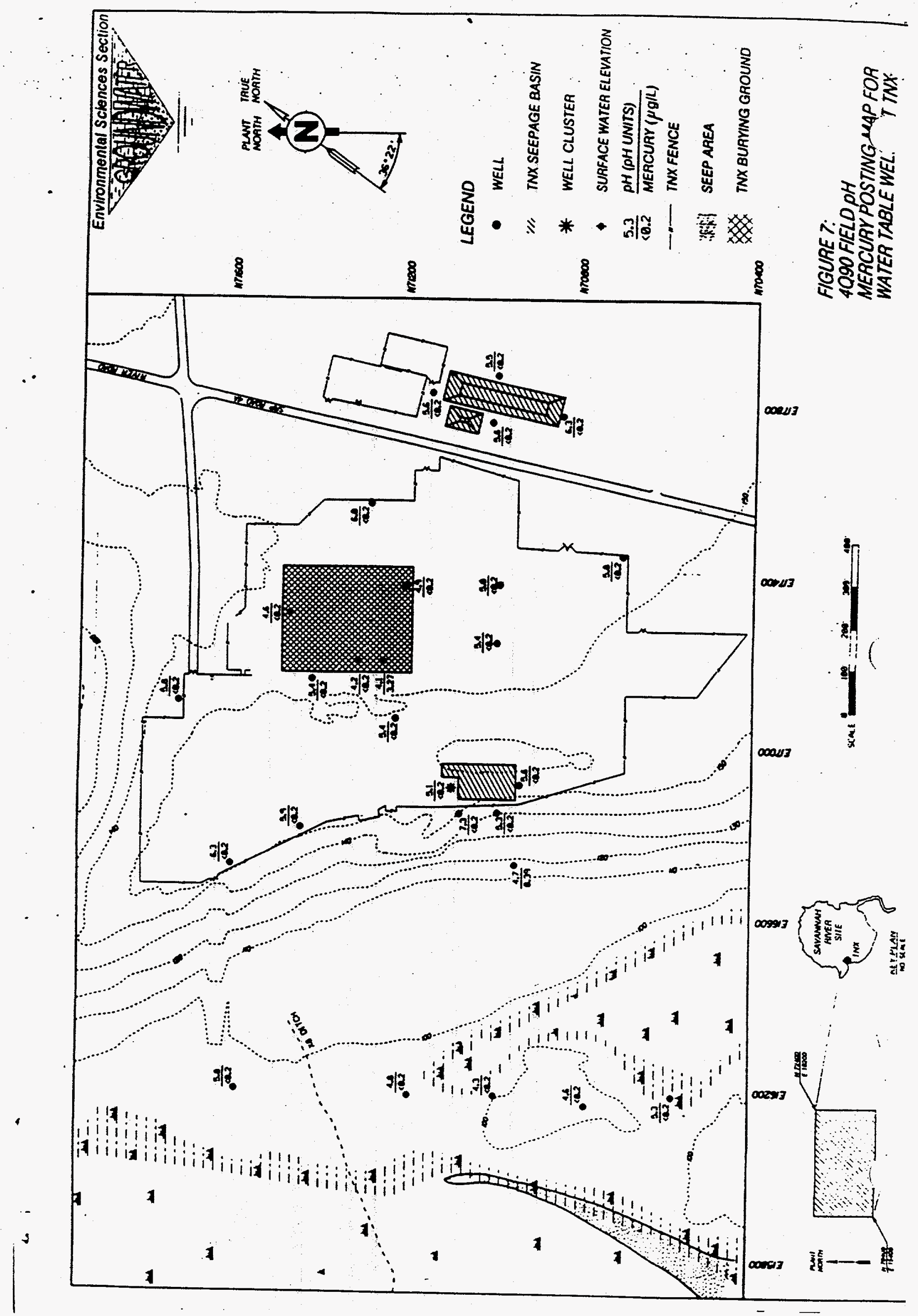




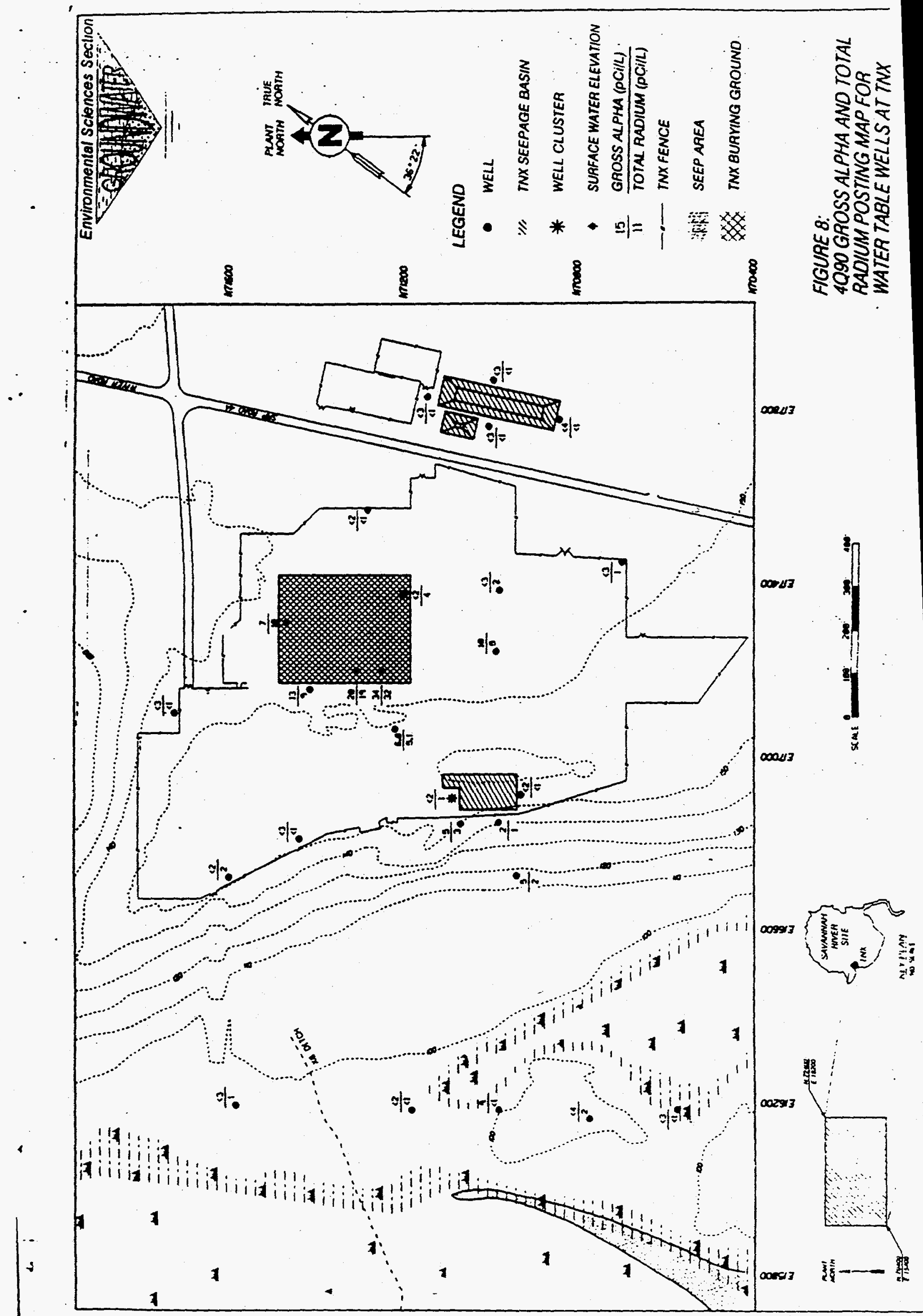




\section{Summary of Operable Unit Risks}

- This interim action will serve an incremental step in addressing contamination in the TNX Area and is not intended as a final action. As required by CERCLA, development and selection of final cleanup activities will depend upon the extent of vadose zone contamination. the effectiveness of this interim action, and the results of the Baseline Risk Assessment. The Baseline Risk Assessment will evaluate the current and potential risks to human health and the environment from contamination in the TNX Area. Based upon the results of that assessment, appropriate cleanup alternatives will be developed to fully address site risks.

\section{Contaminated Media}

Contaminated media at the TNX Area includes groundwater, surface water, and the soil above the water table. The focus of this interim action is the contaminated groundwater.

\section{Contaminants of Concern}

As reflected in Table 1, a number of contaminants have been detected in the groundwater system at levels exceeding health-based standards. The primary contaminant of concern for this interim action is TCE. While carbon tetrachloride and nitrates also appear to be migrating offsite, the plume distributions of TCE and carbon tetrachloride coincide, but the concentrations of carbon tetrachloride are significantly lower than TCE concentrations. The concentration of nitrates leaving the TNX Area is at or slightly exceeds health-based standards and does not pose as significant a threat as TCE. The chemicals of concern will continue to be evaluated for this unit as this interim action is implemented and further investigations in the TNX Fundamental Study Area are conducted.

\section{Interim Risks}

The TNX Groundwater Interim Risk Evaluation (IRE) was performed to determine current risks to human health and the environment and to determine if the risk was high enough (greater than $1 \times 10^{4}$ ) to require immediate remedial action. Results of the IRE indicate that the contaminant responsible for the largest portion of the risk to the onsite worker is TCE (see Figure 9). The largest risk to the onsite worker is through contact with contaminated soil and water at the groundwater outcrop in the swamp during sampling. The IRE shows that under current conditions, the onsite worket is not exposed to contaminants at concentrations that will produce an unacceptable risk to human health (see Figure 10).

While the contaminants in the groundwater system exceed SDWA drinking water standards, the contaminated groundwater is not being used, nor is it planned to be used while the site is controlled by DOE. Use of this groundwater as a drinking water source would present unacceptable risk levels. The goals of this action are to mitigate the migration of contaminants and prevent the further degradation of the groundwater system. These goals are consistent with the expectations of the NCP and EPA guidance on addressing groundwater contamination. 


\section{Description of Alternatives}

- Interim action alternatives developed for the TNX Area Groundwater Operable Unit include:

Alternative 1

No Interim Action, Maintain Existing Institutional Controls

\section{Alternative 2}

Hybrid Groundwater Corrective Action, the hybrid groundwater corrective action includes groundwater extraction wells with an air stripper and a recirculation well.

\section{Alternative 1-No Interim Action, Maintain Existing Institutional Controls}

Alternative 1 would include no interim cleanup activities. Under the no action alternative, existing groundwater contamination would gradually be reduced with time and distance through attenuation processes, such as biodegradation or dispersion. Contaminated groundwater would continue to migrate west toward the swamp and the Savannah River.

\section{Treatment Components}

No treatment would be implemented under Alternative 1 .

Engineering Controls

No engineering controls would be executed under this alternative.

Institutional Controls

Access to SRS is controlled at primary roads by continuously manned barricades. Other roads entering the site are closed to traffic by gates or barriers. The entire SRS facility is surrounded by an exelusion security fence, except along the Savannah River. SRS is posted against trespassing under Federal and state statutes.

Implementation Requirements

This alternative is readily implementable.

Estimated Construction and Operation and Maintenance Costs

Costs associated with Alternative 1 include groundwater monitoring and annual reporting. Groundwater monitoring and reporting is estimated to be \$20,000/year. 
ARARs Associated with the Considered Alternative

Applicable or Relevant and Appropriate Requirements (ARARs) are Federal and state environmental regulations that establish standards that remedial actions must meet. There are three types of ARARs:

- chemical-specific

- location-specific

- action-specific

No Action-specific ARARs are associated with Alternative 1. The only potential locationspecific ARAR associated with Alternative 1 is related to the Clean Water Act.

\section{Alternative 2-Hybrid Groundwater Corrective Action}

Alternative 2, the Hybrid Groundwater Corrective Action, includes groundwater extraction wells with an air stripper and a recirculation well. The extraction wells and air stripper would be used to remove and rear the groundwater exceeding the cleanup goal in the TNX Area Groundwater Operable Unit. A recirculation well installed upgradient of the extraction wells would provide in sizu treatment of contaminated groundwater and may stimulate the natural soil bacteria to degrade some of the contamination while in the aquifer. Air emissions from the air stripper and recirculation well will be treated as necessary to comply with SCDHEC air pollution regulations.

Treatment/Engineering Controls

\section{Recirculation Wells}

Recirculation wells are an cmerging technology for in situ cleanup of CVOC contaminated groundwater. In recirculation wells, air is injected into a groundwater well. As the air rises to the surface in the well. it removes CVOCs from the water by air suripping. Additionally. the air causes groundwater to flow upward in the well establishing a circulation system where water is drawn into the bottom and discharged at the water table. The air is collected by a vacuum at the surface for treatment (see Figure 11). The vacuum also recovers soil vapor from the unsanurated zone resulting in additional cleanup.

\section{Extraction Wells with an Air Stripper}

The flow of contaminated groundwater is intercepted by a series of water wells known as extraction wells. The extraction wells are used to drawdown the water table and collect contaminated groundwater. Drawdown from the extraction wells produces a capture zone that prevents the further migration of contamination from the site (see Figure 12). The contaminated groundwater that is collected by the extraction wells will be treated by an air stripper. Treated groundwater will be discharged to a permittod outfall. The air stripper can also be used to treat contaminated water from other cleanup activities such as groundwater samping. Air emission from the air stripper and recirculation well will be treated as necessary to comply with SCDHEC air pollution regulations.

Mercury, gross alpha, and nitrate will be monitored in the effluent from the treatment system to ensure that they do not exceed discharge limits. If they begin to exceed discharge limits. 
the well causing the exceedance will be identified through sampling. and discharges from that well will be treated using methods similar to ion exchange or reverse osmosis.

\section{Performance Objectives}

The performance objectives of the interim action are to:

- Stabilize the operable unit and prevent the further degradation of the groundwater system by containing the portion of the plume with $>500 \mu \mathrm{g} / \mathrm{LCE}$. This concentration level was selected based upon calculations performed associated with the IRE and technical considerations for well placement and system performance. Controlling the portion of the plume with $>500 \mu g /$ TCE will also control and treat the area with the highest concentrations of other CVOCs and nitrates.

- Maintain risks associated with potential exposure pathways within acceptable limits.

- Implement an action that will not be inconsistent with and facilitate potential future cleanup efforts.

The interim action cleanup goal was developed using a risk-based approach to protect humans in the interim exposure scenario with the highest risk of cancer, the onsite worker. In the IRE, the onsite worker was exposed to $930 \mu \mathrm{g} / \mathrm{L}$ of TCE in the groundwater outcrop. The cleanup goal of the interim action is to reduce the maximum TCE concentration in the plume to $\leq 500 \mu \mathrm{g} / \mathrm{L}$ ensuring that the concentrations at the seep do not present a risk to human health and the environment. The $500 \mu g / L$ concentration for TCE was selected based on the results of the IRE and the concentration of TCE that is admissable in a solid waste (TCLP level) before it is considered a hazardous waste. This remedy will provide protection of human health by ensuring that the most highly exposed person in the IRE does not receive a dose of TCE that results in an unacceptable cancer risk. CVOC concentration in the recovery wells, $\mathrm{TNX}$ monitoring wells, air stripper influent and effluent, and air stripper offgas will be monitored to evaluate system performance.

\section{Benefits}

In the Hybrid Groundwater Corrective Action, the advantages of one technology addresses the disadvantages of the other resulting in a robust cleanup system. The benefits of the Hybrid Groundwater Corrective Action are listed below.

\section{Recirculation Well}

- in situ treatment of contaminated groundwater

- in situ biodegradation reduces cleanup times

- conserves groundwater resources during cleanup

- potential for cleaning up the unsarurated zone using soil vapor extraction

Pump and Treat

- stops migration of contaminated water exceeding interim cleanup goals

- collects and treats contaminated water

- provides infrastructure for handling secondary waste associated with cleanup

- enhances transport of nutrients from recirculation well for in situ cleanup 
Institutional Controls

Public access to SRS is controlled by existing security personnel and security equipment. a discussed under Alternative 1. The existing SRS security controls will be maintained as par of normal SRS operations.

Implementation Requirements

The implementation requirements for the Hybrid Groundwater Corrective Action will include the following:

- installing groundwater recovery wells to capiure the portion of the plume with $>500 \mu \mathrm{g} /$ TCE

- constructing the air stripper to treat the TCE and other CVOCs in the recovered groundwater

- installing a recirculation well to enhance the natural in situ biocegradation of TCE and other CVOCs in the groundwater

Standard drilling techniques for unconsolidated sediments will be used when possible. The recirculation well uses a larger than normal borehole and may require special materials to drill the well. The air stripper and components of the recirculation well are standard industrial equipment and are readily available. The air lift recirculation well is a relatively new remediation technique and will require some startup testing to evaluate the optimal operating conditions.

\section{Estimated Construction and Operation and Maintenance Costs}

The costs for Alternative 2 are estimated to be $\$ 600,000$. Costs include construction. monitoring, and maintenance of the recireulation well and pump and treat system.

\section{ARARs Associated with the Considered Alternative}

The ARARs for the Hybrid Groundwater Corrective Action are listed in Table 2. The National Primary Drinking Water Standards (MCLMCLGs) will not be ARARs because they are beyond the scope of the interim action. 


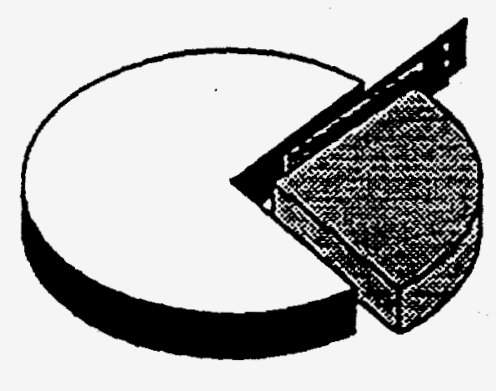

Figure 9. Sources of Rist to Onsite Worker

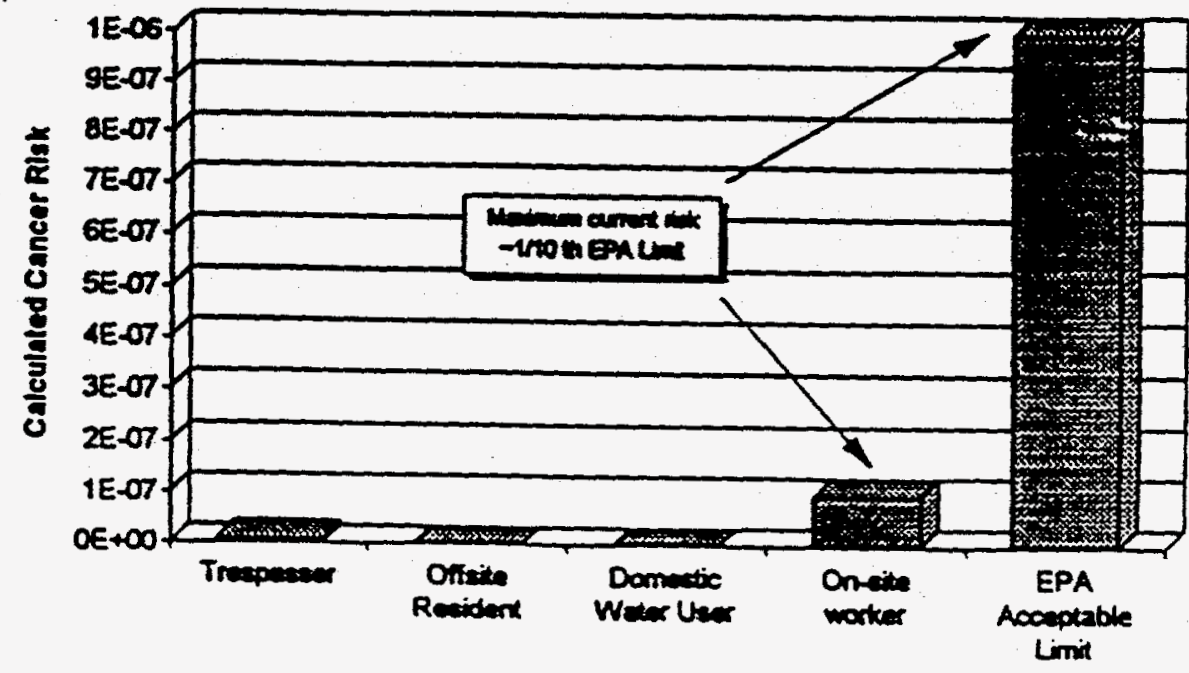

Exposure Scomanio

Figure 10. Risks for Different Exposure Scenarios 
Flow patterns for a Recirculation Well System

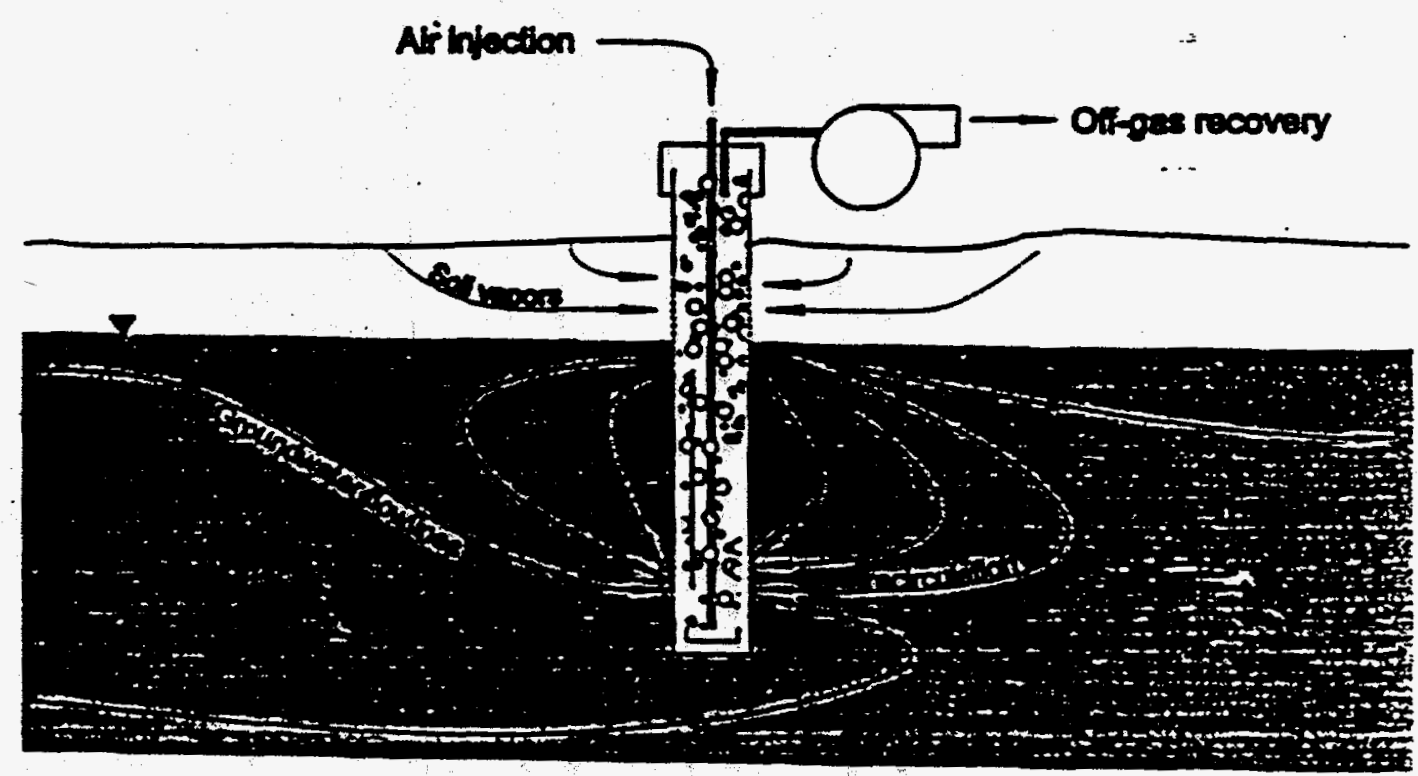

Figure 11. Flow Patterns for a Recirculation Well System 


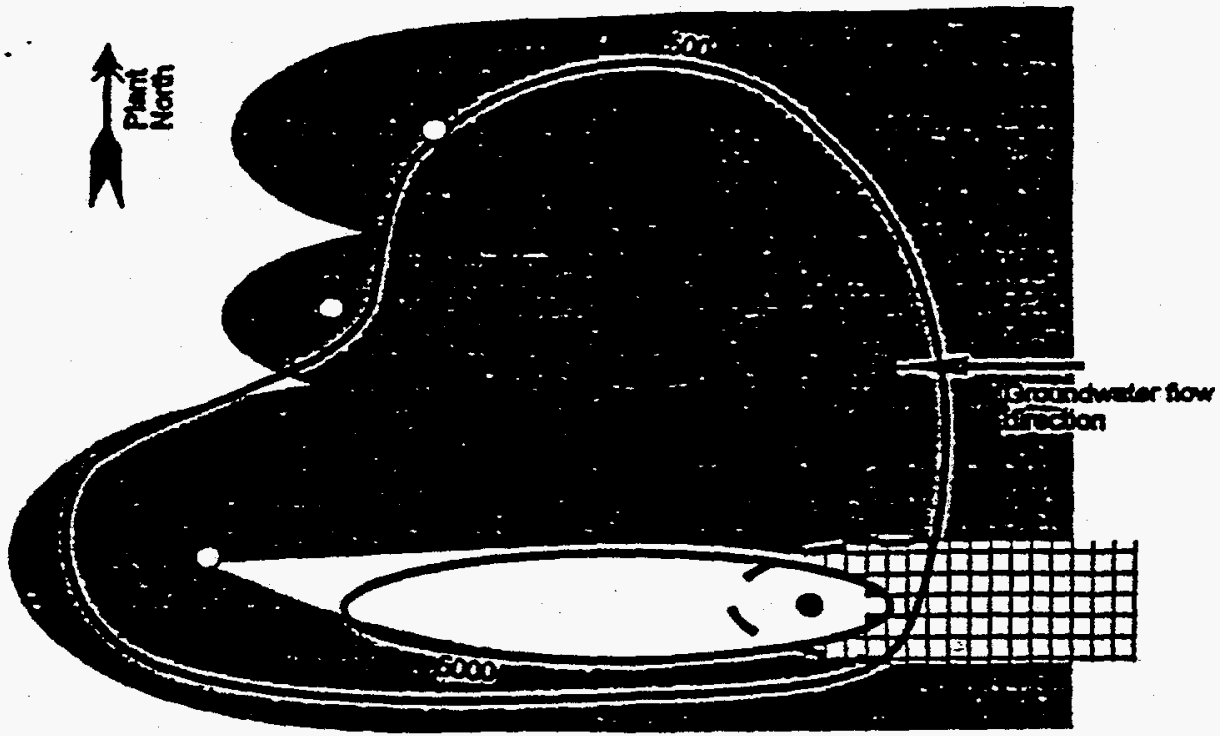

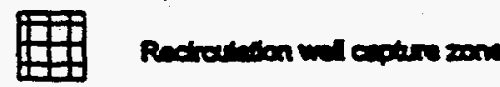

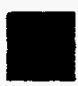

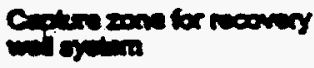

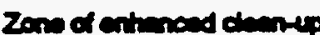
by bisuruditen

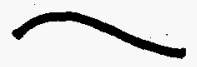

Thatocoutom (uol)

Recterexton und

0

Recown What

The Hybrid Groundwater Corrective Action is designed to stabilize the groundwater contrinination through contsinmen of the most contaminated groundwater. Contrinment of the portion of the plume with $>500$ ug $/$ TCE will be sccom plished using 3-5 recovery wells cumulatively pumping up to 30 gallons per minute. A recirculation well will be installed in the most contaminated portion of the groundwater being contained by the recovery wells to accelerate the reduction of contamination levels. The bottom of the recirculation well recovers groundwater and the top of the recirculation recharger the contaminated equifer with treated groundwater containing nurrients to stimulate in situ cleanup of the contamination downgradient of the recirculation well. As the wather rises in the recirculation well, the nutrients in the air, used to treat the contamiannts. dissolve into the water (soe Figure 11). The recovery wells can be used to direct the recharge from the rocirculation well to expand the zone of in situ cleanup. The hypothetical capture zone above was developed using a simplifiec model of the groundwater flow a TNX based on data from monitoring wells and pumping tests.

Figure 12. Capture Zone of a Hypothetical Hybrid Groundwater Corrective Action for TNX 
Table 2. Applicable or Relevant and Appropriate Requirements (ARARs) and Guidance for the Hydraulic Contain- ( ment of Offsite Groundwater

\begin{tabular}{|c|c|c|c|c|}
\hline Actions & Requirements & Prerequisites & Federal citation & $\begin{array}{l}\text { South Caro- } \\
\text { lina Code of } \\
\text { Lows } \\
\end{array}$ \\
\hline \multicolumn{5}{|c|}{ CHEMICALSPECIFIC } \\
\hline $\begin{array}{l}\text { Treatment of con- } \\
\text { taminated } \\
\text { groundwater }\end{array}$ & $\begin{array}{l}\text { Discharge must not exceed } \\
\text { DCGs for radionuclides; dis. } \\
\text { charge of radionuclides must not } \\
\text { excoed } 1 \text { rad/day for protection } \\
\text { of aguatic organisms }\end{array}$ & $\begin{array}{l}\text { Direce discharge of groundwater to } \\
\text { a surface water body - TBC guid- } \\
\text { ance }\end{array}$ & DOE Order 5400.5 & \\
\hline Air Stripping & $\begin{array}{l}\text { Environmental Permits to con- } \\
\text { struet and operate }\end{array}$ & $\begin{array}{l}\text { Discharge of toxic air pollutants } \\
\text { (trichloroethylene and tetrectoro- } \\
\text { ethylene) - Substantive requitre } \\
\text { ments are applicable }\end{array}$ & & $\begin{array}{l}\text { SC-R. 61-62.1. } \\
\text { SC-R. 61-62.5. } \\
\text { Standard Number } \\
8\end{array}$ \\
\hline \multirow[t]{2}{*}{$\begin{array}{l}\text { Protection of the } \\
\text { general public } \\
\text { from all sources } \\
\text { of radiation }\end{array}$} & $\begin{array}{l}\text { The general public must not } \\
\text { receive an effective dose equiva- } \\
\text { lent greater than } 100 \text { mrem/year }\end{array}$ & $\begin{array}{l}\text { Dose received by the general pub- } \\
\text { lic from all sources of rediation } \\
\text { exposure at a DOE facitity - TBC } \\
\text { guidance }\end{array}$ & DOE Onder 5400.5 & \\
\hline & $\begin{array}{l}\text { All releases of radioective mate- } \\
\text { rial must be "as low as reason- } \\
\text { ably achievable" (ALARA) }\end{array}$ & $\begin{array}{l}\text { Releases of radionctive material } \\
\text { from DOE activities - TBC guid- } \\
\text { ance }\end{array}$ & DOE Onder 5400.5 & \\
\hline $\begin{array}{l}\text { Protection of the } \\
\text { general public } \\
\text { from all sources } \\
\text { of air emissions }\end{array}$ & $\begin{array}{l}\text { No member of the general public } \\
\text { shall receive an effective dose } \\
\text { equivalent greater than } 10 \text { mrem } \\
\text { year }\end{array}$ & $\begin{array}{l}\text { Emissions of radionuclides to the } \\
\text { ambient air from DOE facilities - } \\
\text { Applicable }\end{array}$ & $\begin{array}{l}40 \text { CFR 61.92: DOE } \\
\text { Order 5400.5 }\end{array}$ & \\
\hline \multirow[t]{2}{*}{ Worker protection } & $\begin{array}{l}\text { Maintain worker exposures to } \\
\text { ALARA }\end{array}$ & $\begin{array}{l}\text { Internal and external sources of } \\
\text { continuous exposure to occupa- } \\
\text { tional workers at a DOE facility - } \\
\text { TBC guidance }\end{array}$ & DOE Onder 5480.11 & \\
\hline & $\begin{array}{l}\text { Maximum exposure to occupa- } \\
\text { tional workers: } 5 \text { rem/year (sto- } \\
\text { chastic): } 50 \text { rem/year } \\
\text { (nonstochastic) effective dose } \\
\text { equivalent }\end{array}$ & $\begin{array}{l}\text { Internal and external sources of } \\
\text { continuous exposure to occups. } \\
\text { tional workers at a DOE facility - } \\
\text { TBC guidance }\end{array}$ & DOE Order 5480.11 & \\
\hline \multicolumn{5}{|c|}{ ACTION-SPECTFIC } \\
\hline Erosion Control & $\begin{array}{l}\text { Develop a plan for erosion sedi- } \\
\text { ment control }\end{array}$ & $\begin{array}{l}\text { Land disturbing activities - Appli- } \\
\text { cable }\end{array}$ & & SC 72-300 \\
\hline \multirow[t]{3}{*}{ Well Construction } & $\begin{array}{l}\text { Construction by a certified driller } \\
\text { is required }\end{array}$ & Drilling water wells - Applicable & & SCR.61-71 \\
\hline & $\begin{array}{l}\text { Standards for construction, main- } \\
\text { tenance, and operation of all } \\
\text { wells }\end{array}$ & Drilling waier wells - Applicable & & SCR.61-71 \\
\hline & $\begin{array}{l}\text { Standards for construction of } \\
\text { injection wells }\end{array}$ & $\begin{array}{l}\text { Construction injection well (recir- } \\
\text { culating wells) - Applicable }\end{array}$ & 40 CFR 144-147 & SCR.61-87 \\
\hline
\end{tabular}


Table 2. Applicable or Relevant and Appropriate Requirements (ARARs) and Guidance for the Hydraulic Containment of Offsite Groundwater

\begin{tabular}{|c|c|c|c|c|}
\hline Actions & Requirements & Prerequisites & Federal citation & $\begin{array}{l}\text { South Caro- } \\
\text { lina Code of } \\
\text { Laws }\end{array}$ \\
\hline \multirow[t]{2}{*}{$\begin{array}{l}\text { Discharge of } \\
\text { treated groundwa- } \\
\text { ter to stream }\end{array}$} & $\begin{array}{l}\text { Discharge must comply with the } \\
\text { effluent limitation of the NPDES } \\
\text { permit SC } 0000175\end{array}$ & $\begin{array}{l}\text { Point sources discharge to waters } \\
\text { of the United States - Applicable }\end{array}$ & 40 CFR 122 & SCR.61.9 \\
\hline & $\begin{array}{l}\text { Discharges to streams must meet } \\
\text { the established water quality } \\
\text { standards }\end{array}$ & $\begin{array}{l}\text { Discharges lo surface waters of the } \\
\text { State - Applicable }\end{array}$ & & SCR.61-68 \\
\hline \multirow[t]{2}{*}{ Air Stripping } & $\begin{array}{l}\text { Stare of S.C. requires a permit to } \\
\text { build and operate a wastewater } \\
\text { facility }\end{array}$ & $\begin{array}{l}\text { Construction and operation of an } \\
\text { industrial wastewater treatment } \\
\text { facility - Substantive requin- } \\
\text { ments and applleable }\end{array}$ & & $\begin{array}{l}\text { S.C. Pollution } \\
\text { Control.Act Tite } \\
48-1-110\end{array}$ \\
\hline & $\begin{array}{l}\text { A NESHAP evaluation to deter- } \\
\text { mine if source of radionuclide } \\
\text { emission requires EPA approval }\end{array}$ & $\begin{array}{l}\text { Radionuclides other than radon } \\
\text { from DOE facilicies - Substantive } \\
\text { requirements are applicable }\end{array}$ & 40 CFR 61.96 & \\
\hline
\end{tabular}

\section{Acronyms used in Table 2}

$\mathrm{TBC}=$ to be considered

DCGs $=$ derived concentration guide

$\mathrm{CFR}=$ Code of Federal Regulations

DOE $=$ Department of Energy

EPA = Environmental Protection Agency

NPDES $=$ National Pollutant Discharge Elimination System

NESHAP = National Emissions Standards for Hazardous Air Pollutants 


\section{Vill. Summary of Comparative Analysis of Alternatives}

- Each interim response alternative was evaluated using nine criteria developed by the EPA. The criteria were derived from statutory requirements of CERCLA. Section 121. The results of the evaluation are presented in Table 3.

\section{Descriptions of Nine Evaluation Criteria}

- Overall Protection of Human Health and the Environment. This addresses whether a remedy provides adequate protection and describes how risks posed through each pathway are eliminated, reduced, or controlled through treatment, engineering controls, or institutional controls.

- Long-Term Effectiveness and Permanence. This refers to the magnitude of residual risk and the ability of a remedy to maintain reliable protection of human health and the environment over time once cleanup goals are met.

- Shor-Term Effectiveness. This refers to the speed with which the remedy achieves protection, as well as the potential for a remedy to create adverse effects on human health and the environment that may result during the construction and implementation period.

- Reduction of Toxicity, Mobility, or Volume through Treatment. The remedial alternatives are assessed based on the degree to which they employ treatment that reduces toxicity, mobility, or volume, including how treatment is used to address the principal threats posed by a media-specific operable unit.

- Implementability. This refers to the technical and administrative feasibility of a remedy, including the availability of materials and services that may be used to implement the chosen solution.

- Compliance with Applicable or Relevant and Appropriate Requirements (ARARs). This criterion addresses whether a remedy will meet the ARARs of other Federal and state environmental statutes.

- Cost. This includes capital, operation, and maintenance costs.

- State Acceptance. Based on its review of the proposed interim action, this indicates whether the state concurs with, opposes, or has no comment on the preferted alternative.

- Community Acceptance. Acceptance by the surrounding community will be assessed in the Record of Decision following a review of the public comments received on the proposed interim actions. 
Table. 3 Evaluation of Interim Response Actions

\begin{tabular}{|c|c|c|}
\hline \multirow[b]{2}{*}{ Evaluation Criteria } & \multicolumn{2}{|c|}{ Alternatives } \\
\hline & (1) No action & $\begin{array}{l}\text { (2) Hybrid Groundwater Corrective } \\
\text { Action }\end{array}$ \\
\hline $\begin{array}{l}\text { Overall Protection of Human } \\
\text { Health and the Environment }\end{array}$ & Minimal & High \\
\hline Compliance with ARARs & $\begin{array}{l}\text { This alternative will not be in compliance } \\
\text { with the Safe Drinking Water Act in the } \\
\text { following areas: } \\
\text { - contaminant concentrations in the } \\
\text { groundwater and local surface water } \\
\text { exceeds PDWS } \\
\text { surface water concentrations in local } \\
\text { seeps do not meet NPDES require- } \\
\text { ments }\end{array}$ & $\begin{array}{l}\text { The water treatment plant (air stripper) will } \\
\text { be constructed and operated in full compli- } \\
\text { ance with wastewater treatment plant regu- } \\
\text { lations. Treated groundwater will meet } \\
\text { NPDES requirements and offgas from the } \\
\text { treatment system will meet Clean Air Act } \\
\text { regulations. }\end{array}$ \\
\hline $\begin{array}{l}\text { Long-term effectiveness and } \\
\text { permanence }\end{array}$ & $\begin{array}{l}\text { This evaluation criterion does not apply to } \\
\text { Interim Actions. }\end{array}$ & Same as no action. \\
\hline $\begin{array}{l}\text { Reduction of toxicity, mobil- } \\
\text { ity, or volume through treat- } \\
\text { ment }\end{array}$ & None & $\begin{array}{l}\text { Air stripping removes the contaminants } \\
\text { from the recovered groundwater, reducing } \\
\text { its toxicity. Volume of groundwater that } \\
\text { may pose a risk to onsite workers will be } \\
\text { reduced through reduction of contaminant } \\
\text { mass in the portion of the plume exceeding } \\
\text { the interim goal. }\end{array}$ \\
\hline Short-term effectiveness & $\begin{array}{l}\text { This alternative does not provide a short- } \\
\text { term remedy for preventing discharges of } \\
\text { contaminated groundwater to the swamp. }\end{array}$ & $\begin{array}{l}\text { Groundwater recovery will immediately } \\
\text { begin to reduce the amount of contaminant } \\
\text { remaining in the subsurface and control the } \\
\text { migration of contaminated groundwater } \\
\text { into the swamp. }\end{array}$ \\
\hline Implementability & This alternative is already in place. & $\begin{array}{l}\text { All of the technologies in this alternative } \\
\text { are currently available. Air stripping is } \\
\text { extremely efficient and requires minimal } \\
\text { maintenance. This system has a wide range } \\
\text { of operating conditions and as result, reme- } \\
\text { diation system upgrades can be easily } \\
\text { incorporated. }\end{array}$ \\
\hline Cost (for comparison only) & $\begin{array}{l}\text { Capital Cost: } \$ 0 \\
\text { Operation and Maintenance (O\&M) } \\
\text { Costs: approximately } \$ 20,000 \text { per year } \\
\text { Months to Implement: already in place }\end{array}$ & $\begin{array}{l}\text { Capital Cost: } \$ 600,000 \\
\text { Operation and Maintenance (O\&M) } \\
\text { Costs: approximately } \$ 100,000 \\
\text { Months to Implement: } 18-24\end{array}$ \\
\hline State acceptance & $\begin{array}{l}\text { This alternative is not acceptable to } \\
\text { SCDHEC. }\end{array}$ & This altemative is acceptable to SCDHEC. \\
\hline Community acceptance & See responsiveness summary. & See responsiveness summary. \\
\hline
\end{tabular}




\title{
iX. Selected Remedy
}

\begin{abstract}
- Alternative 2 is the selected alternative for this interim action. This alternative will provide the best balance between the need for prompt action for groundwater remedial actions and the current site conditions and exposure scenarios. The hybrid groundwater corrective action will achieve the goals highlighted for this action and will serve as an incremental step in addressing environmental contamination within the TNX Fundamental Study Area and SRS.
\end{abstract}

The hybrid groundwater corrective action system will stabilize the portion of the plume with $>500 \mu g / \mathrm{TCE}$ as it is generally depicted in Figure S. However. if the area containing TCE leveis exceeding $500 \mu \mathrm{g} / \mathrm{L}$ has expanded, the area that will be intercepted will be expanded accordingly. Samples from existing monitoring wells as well as samples from the influent and effluent from the air strippers, air emissions from the air stripper, and the recirculation well will be used to monitor the performance of the interim action. The details of the monitoring will be discussed in the operating and maintenance plan for the hybrid groundwater corrective action system. 


\section{Statutory Determination}

- The National Contingency Plan (40 CFR 300.430(e)(9)) sets forth nine evaluation criteria that provide the basis for evaluating alternatives and subsequent selection of a remedy. The selected altemative. Altemative 2, was evaluated with respect to the five statutory findings. as required for interim actions under CERCLA. The results of the evaluation are as follows:

Protection of Human Health and the Envinonment. Alternative 2 will mitigate the risks of exposure to contaminated surface water by stopping the migration of groundwater containing CVOCs above the interim cleanup goal before it reaches the swamp and utilizing existing administrative controls. Additionally, removing CVOC-contaminated groundwater will reduce the future risk of exposure to contaminated groundwater through ingestion.

Attainment of ARARs. All ARARs pertaining to the treatment and disposal of contaminated groundwater will be met by the selected alternative (Table 2). The selected alternative will clean up the contaminated groundwater to meet the interim cleanup goals.

Cost Effectiveress. The recovery well system is a cost- effective method of providing hydraulic containment of the groundwater contamination beneath an operating facility where physical barriers are not practical. The recovery system also provides an advantage over the physical barriers due to the benefits of contaminant removal. Air stripping is an efficient method for removing CVOCs from groundwater and is a well established treatment method for contaminated groundwater.

Recirculation wells are new technology for cleaning up CVOCs and there is little data on the cost-effectiveness of the technology. Cost-effective methods such as air lift pumping and air stripping play a major role in recirculation wells. The cost-effective components along with potential for in situ groundwater cleanup indicate that recirculation wells will be economically feasible.

Utilization of Permanent Solutions and Alternative Treatment Technologies or Resource Recovery Technologies to the Maximum Extent Practicable. The proposed alternative relies heavily on treatment technologies to remove CVOCs from the groundwater. Treatment is a principal element of this interim action and is achieved through enhanced in situ biodegradation and air stripping of groundwater contaminated with VOCs. However, this action is an interim action and is not designed or expected to be final. The selected remedy represents the best balance of tradeoffs with respect to perinent criteria given the limited scope of the action.

Preference for Treatment as a Principal Element. The principal threat in the TNX Groundwater Operable Unit is trichoroethylene. The selected alternative uses treatment as a principal element of the Hybrid Groundwater Remediation System. Specifically, the selected alternative uses air stripping and in situ bioremediation to treat the principal threat. Furthermore, the selected alternative does not include any element that requires storage of waste. Although this statutory preference is partially addressed in this remedy, the preference for treatment as a principal element will be addressed by the final response action for this unit. 


\section{Explanation of Significant Changes}

- There were no significant changes to the LAPP as a result of the public comments. 


\section{References}

- DOE (U. S. Departunent of Energy). 1987, Final Environmental Impact Statement-Waste Management Activities for Groundwater Protection Savannah River Plant. Aiken. South Carolina. DOE/EIS-0120, Savannah River Plant Operations. Aiken. SC 29808.

FFA. Federal Facility Agreement for the Savannah River Site. Administrative Docket No. 09-05-FF, Effective Date: August 16. 1993.

Nichols, R. L., 1992. Chanacterization of Shallow Groundwater at TNX (U), WSRC-TR-92508, Rev. 0.

WSRC, 1991b, SRS Public Involvement Plan, WSRC-RP-91-445, Rev 2. September 8. 1992, Westinghouse Savannah River Site, Aiken. SC 29802.

WSRC, Assessment of Tritium in the Savannah River Site Environment (U). WSRC-TR-93214. October 1993, Westinghouse Savannah River Site, Aiken, SC 29802. 


\title{
Responsiveness Summary
}

\author{
General Response
}

During the 30 day comment period, a request for a public meeting was received. The public comment period was extended an additional 30 days so the public meeting could be held. The public information meeting was held on October 11:1994, in Aiken. South Carolina.

The public meeting was divided into three main segments: a general introduction section, a discussion about the proposed TNX groundwater interim action. and a discussion about the proposed D-Area Oil Seepage Basin interim action. The TNX discussion was broken into a general information and background segment, a discussion and question/answer session about the proposed interim action, and finally, an opportunity for formal commenting. No formal comments were received at the public meeting.

During the public comment period, limited written comments were received. In general. comments concerning the proposed action for the TNX groundwater unit addressed technical details regarding treatment of the extracted groundwater. No comments were received which opposed the proposed action. During the public information meeting, several questions were raised regarding selection of the interim action goals and general information on the contaminants present at the site. No comments were received which opposed the proposed action. The minutes of the public meeting are available in the administrative record file.

During the public information meeting, suggestions were received from the Energy Research Foundation on potential improvements to the meeting format. These comments will be evaluated, and to the extent possible, the recommendations will be followed.

Written comments were received from members of the public and the Energy Research Foundation.

\section{Specific Comments}

\section{Comment}

A series of public meetings should be held.

\section{Response}

A public meeting was held on October 11, 1994, in Aiken. SC. to discuss the proposed interim action. In general. the Department of Energy plans to conduct periodic public information meetings to review the general status of significant cleanup operations, solicit public input on specific remedial actions, and provide an opportunity for the public to discuss cleanup issues with DOE and the regulators. 


\section{Commeat}

\section{Energy Research Foundation}

Columbia, SC

... The phrase "treated as necessary" on page 11 begs further definition as to whether the air will be routinely treated. or whether it will be treated only when it goes above a certain monitoring threshold. If so, what is the threshold, and is it consistent with the State and Federal regulations? However, air emissions will be monitored to ensure compliance with applicable regulations.

\section{Response}

The treatment threshold is set by the State and Federal air regulations. Discussions with the State and Federal regulators about the anticipated air emissions from the TNX treatment system indicate that no treatment of air emissions will be required.

\section{Comment}

Energy Research Foundation

Columbia, SC

Further. SRS should certify that it has the treatment capability for each of the contaminants that may be present in groundwater that is pumped to the surface for treatment and discharge via the "permitted outfall." The permitted outfall is, presumably, to be a NPDES permitted stream. NPDES permits don't include radioactive materials though, and it's not clear what "discharge limits" SRS will apply. Any surface water discharge that exceeds Federal drinking water standards would not be acceptable - not because it wouldn't be illegal, but because it is probably increasing the risk to the public.

\section{Response}

A wastewater construction permit must be issued by the SCDHEC before the construction of the wastewater treatment plant can begin. All chemical constituents in the groundwater that require treatment prior to discharge at a permitted NPDES outfall in the TNX area will be addressed by the treatment system. SCDHEC does not issue water construction permits uniess all necessary treatment is provided for in the permit application. SRS will meet discharge requirements for radionuclides in compliance with DOE Order 5400.5, which is soon to be 10 CFR 834. The contaminant of concern in the interim has been identified in the LAPP as trichlorocthylene. Stabilization and remediation of the portion of the plume with the highest concentrations of TCE will also address the portion of the plume with the highest concentrations of other contaminants that do not pose an unacceptable health risk during the interim remediation period.

\section{Comment}

Energy Research Foundation

Columbia, SC

Questions about the combined effects of pumping, treating, and releasing contaminated groundwater should be answered before a decision is made. 


\section{Response}

All questions pertaining to the combined effects of pumping, treating. and releasing contaminated groundwater were answered in the public hearing. Specifically, a question to the mobilization of mercury as a result of pumping was asked. The mobile form of mercury is not stable in groundwater at TNX, and as a result, the mercury contamination is highly localized 